\title{
Comparative Analysis of Photocatalytic and Electrochemical Degradation of 4-Ethylphenol in Saline Conditions
}

\author{
Robert Brüninghoff, ${ }^{\dagger}$ Alyssa K. van Duijne, ${ }^{\dagger}$ Lucas Braakhuis, $^{\dagger}$ Pradip Saha, ${ }^{\dagger}$ Adriaan W. Jeremiasse, ${ }^{\S}$ \\ Bastian Mei, ${ }^{\dagger}{ }^{\circ}$ and Guido Mul* ${ }^{*}+$ (1) \\ ${ }^{\dagger}$ PhotoCatalytic Synthesis Group, MESA+ Institute for Nanotechnology, Faculty of Science and Technology, University of Twente, \\ P.O. Box 217, 7500 AE Enschede, The Netherlands \\ ${ }^{\ddagger}$ Department of Environmental Technology, Wageningen University and Research, P.O. Box 17, 6700 AA Wageningen, The \\ Netherlands \\ ${ }^{\S}$ MAGNETO Special Anodes B.V. (an Evoqua brand), Calandstraat 109, 3125 BA Schiedam, The Netherlands \\ Supporting Information
}

ABSTRACT: We evaluated electrochemical degradation (ECD) and photocatalytic degradation (PCD) technologies for saline water purification, with a focus on rate comparison and formation and degradation of chlorinated aromatic intermediates using the same non-chlorinated parent compound, 4-ethylphenol (4EP). At $15 \mathrm{~mA}$. $\mathrm{cm}^{-2}$, and in the absence of chloride $\left(0.6 \mathrm{~mol} \cdot \mathrm{L}^{-1} \mathrm{NaNO}_{3}\right.$ was used as supporting electrolyte), ECD resulted in an apparent zero-order rate of $30 \mu \mathrm{mol} \mathrm{L}{ }^{-1} \cdot \mathrm{h}^{-1}$, whereas rates of $\sim 300 \mu \mathrm{mol} \mathrm{L}{ }^{-1} \cdot \mathrm{h}^{-1}$ and $\sim 3750 \mu \mathrm{mol} \mathrm{L}{ }^{-1} \cdot \mathrm{h}^{-1}$ were computed for low $\left(0.03 \mathrm{~mol} \cdot \mathrm{L}^{-1}\right)$ and high $\left(0.6 \mathrm{~mol} \cdot \mathrm{L}^{-1}\right) \mathrm{NaCl}$ concentration, respectively. For PCD, initial rates of $\sim 330 \mu \mathrm{mol} \mathrm{L}{ }^{-1} \cdot \mathrm{h}^{-1}$ and $205 \mu \mathrm{mol} \mathrm{L}{ }^{-1} \cdot \mathrm{h}^{-1}$ were found for low and high $\mathrm{NaCl}$ concentrations, at a photocatalyst $\left(\mathrm{TiO}_{2}\right)$ concentration of $0.5 \mathrm{~g} \cdot \mathrm{L}^{-1}$, and illumination at $\lambda_{\max } \approx 375 \mathrm{~nm}$, with an intensity $\sim 0.32$

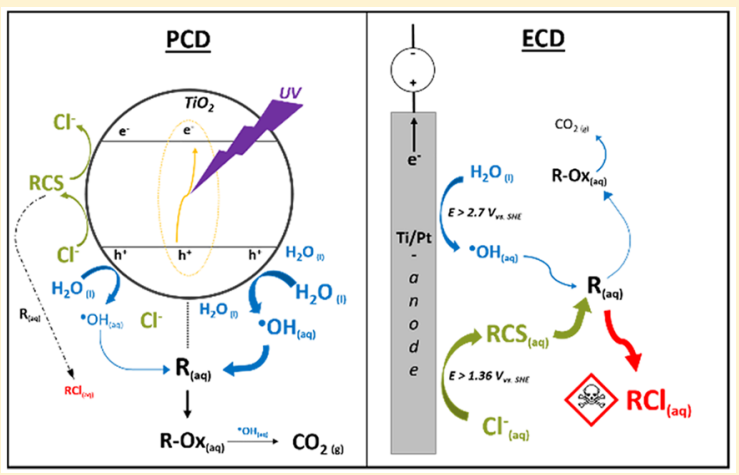
$\mathrm{mW} \cdot \mathrm{cm}^{-2}$. In the chlorine mediated ECD approach, significant quantities of free chlorine (hypochlorite, $\mathrm{Cl}_{2}$ ) and chlorinated hydrocarbons were formed in solution, while photocatalytic degradation did not show the formation of free chlorine, nor chlorine-containing intermediates, and resulted in better removal of non-purgeable hydrocarbons than ECD. The origin of the minimal formation of free chlorine and chlorinated compounds in photocatalytic degradation is discussed based on photoelectrochemical results and existing literature, and explained by a chloride-mediated surface-charge recombination mechanism.

\section{INTRODUCTION}

Water pollution is one of the greatest challenges of modern society. ${ }^{1,2}$ The treatment of polluted water to enable its reuse is essential, ${ }^{3}$ while efficient removal of (recalcitrant) organic pollutants, present in low concentrations, requires development of innovative technology. ${ }^{4-7}$ Particularly difficult is treatment of industrial effluents containing high amounts of sodium chloride, which impedes biological treatment due to negative effects of the $\mathrm{NaCl}$ on the microbial flora such as plasmolysis. $^{8,9}$

Advanced oxidation processes (AOP) such as photocatalytic degradation (PCD) or electrochemical degradation (ECD) are promising methodologies for the removal of (recalcitrant) organics in saline conditions. Highly reactive oxygen species (ROS), e.g., hydroxyl radicals $\left({ }^{\bullet} \mathrm{OH}\right)$ are generated oxidatively (anodically) in both methodologies. ${ }^{10}$ Sodium chloride, ubiquitous in many industrial wastewaters, ${ }^{8}$ is known to further enhance degradation rates in ECD, due to (anodic) chloride oxidation and the consecutive formation of reactive chlorine species (RCS: e.g., $\mathrm{Cl}^{\circ}, \mathrm{Cl}_{2}$, or $\left.\mathrm{HOCl}\right) .{ }^{11-15}$ However, the major disadvantage of ECD in saline media is the formation of chlorinated byproducts. ${ }^{12,16-20}$ These byproducts typically induce high water toxicity, and thus deteriorate the environment. $^{21-23}$

For $\mathrm{TiO}_{2}$-based photocatalytic degradation, chloride is usually considered to be an inhibitor. Several mechanisms have been proposed to explain the inhibition: scavenging of holes or OH-radicals by chloride ions; ${ }^{24-27}$ blocking of active surface sites by chloride ions; ${ }^{25,28-32}$ formation of an inorganic salt layer; ${ }^{33}$ or chloride acting as surface-charge-recombinationcenter for photogenerated charge carriers. ${ }^{34}$ Often, more than one mechanism is used to explain the inhibiting effect. ${ }^{35-40}$ In addition, aggregation of $\mathrm{TiO}_{2}$ particles has been reported to reduce the number of absorbed photons influencing degradation rates. ${ }^{41}$ While the inhibiting effect of chloride,

Received: February 27, 2019

Revised: July 3, 2019

Accepted: July 8, 2019

Published: July 8, 2019 
using $\mathrm{TiO}_{2}$ as photocatalyst, has been discussed frequently in the literature, detailed studies regarding the formation of reactive chlorine species (RCS), such as hypochlorite, and chlorinated intermediates in aqueous solution (starting from a nonchlorinated parent molecule) are rare, and the obtained results seem to be inconsistent. For example, negligible amounts of organochloride compounds have been reported during phenol degradation in high saline media $\left[50 \mathrm{~g} \cdot \mathrm{L}^{-1}\right.$ $\mathrm{NaCl}],{ }^{38,42,43}$ which appears to be in disagreement with detection of several chlorinated intermediates arising from the photocatalytic degradation of the azo dye Acid Orange 7 at moderate salinity $\left[5.8-11.8 \mathrm{~g} \cdot \mathrm{L}^{-1}\right]$. $^{39}$

The role of chloride ions in $\mathrm{TiO}_{2}$-based PCD of organic pollutants is thus not fully understood ${ }^{44,45}$ and requires further studies. ${ }^{46}$ In particular, the formation of toxic byproducts needs attention, to reveal the environmental impact of AOPs. ${ }^{4,20,47-52}$

Although some comparative studies between different AOPs, or a combination of technologies have been reported, ${ }^{53-62}$ to the best of our knowledge a comparative study specifically addressing the concentration dependent formation of chlorinated intermediates during ECD, PCD, and photoelectrochemical degradation (PECD), starting from a nonchlorinated parent compound in saline solutions, has not yet been performed.

In this study the influence of $\mathrm{NaCl}$ on the degradation rate and mechanism of the model compound 4-ethylphenol (4EP) is reported. Two salt concentrations, corresponding to brackish $\left(1.75 \mathrm{~g} \cdot \mathrm{L}^{-1}\right)$ and seawater salt concentrations $\left(35 \mathrm{~g} \cdot \mathrm{L}^{-1}\right)$, covering a relevant concentration range of industrial effluents, ${ }^{8}$ have been studied. $\mathrm{TiO}_{2}$ particle suspensions or $\mathrm{TiO}_{2}$ thin films illuminated by UV light were used for PCD and PECD, respectively. A platinized $\mathrm{Ti}(\mathrm{Ti} / \mathrm{Pt})$ anode was utilized for ECD, and the performance compared to a Boron-DopedDiamond (BDD) electrode.

The obtained results clearly demonstrate that the rate of degradation of 4EP in ECD and PECD is mainly the result of chemical chlorination, since free chlorine and various chlorinated hydrocarbons were detected. In contrast, the formation of chlorinated compounds was significantly smaller in PCD, and the overall removal effective, despite an inhibiting effect of chloride.

\section{MATERIALS AND METHODS}

Chemical and Reagents. The following chemicals were used in this study: titanium dioxide (Hombikat UV 100, Sachtleben (Venator)), 4-ethylphenol (Sigma-Aldrich 99\%), sodium chloride (Sigma-Aldrich $\geq 99 \%$ ), sodium nitrate (Sigma-Aldrich $\geq 99.0 \%$ ), demineralized water (Merck MilliQ system, resistivity $>18 \mathrm{M} \Omega \cdot \mathrm{cm}$ ), water (LC-MS grade, Biosolve BV), acetonitrile (LC-MS grade, Biosolve BV), formic acid (98-100\%, LC-MS grade, Merck), 1-(4hydroxylphenyl)ethanol (for synthesis, see the Supporting Information, SI), 2-(4-hydroxylphenyl)ethanol (Sigma-Aldrich 98\%), 4-hydroxybenzaldehyde (Sigma-Aldrich 98\%), 4-hydroxy-acetophenone (Sigma-Aldrich 99\%), 4-ethylresorcinol (Alfa Aesar 98\%), 4-Ethylcatechol (Sigma-Aldrich 95\%), and 2-chloro-4-ethylphenol (AKos $\mathrm{GmbH},>95 \%$ ), 2,6-dichloro-4ethylphenol (AKos $\mathrm{GmbH},>90 \%$ ).

Degradation Experiments. If not otherwise stated, then all experiments were performed in solutions containing $\mathrm{NaCl}$ or $\mathrm{NaNO}_{3}$ at various concentrations $\left(0.03 \mathrm{~mol} \cdot \mathrm{L}^{-1}\right.$ or $0.6 \mathrm{~mol}$. $\left.\mathrm{L}^{-1}\right)$. Sodium nitrate $\left(\mathrm{NaNO}_{3}\right)$ was used for comparison, since
$\mathrm{NaNO}_{3}$ is supposed to be an "inert" water additive in oxidative processes.

Photocatalytic Degradation. Pretreatment of $\mathrm{TiO}_{2}$ photocatalyst, via annealing at $600{ }^{\circ} \mathrm{C}$ for $4 \mathrm{~h}$ (named in the following H600), was performed to achieve an improved photocatalytic performance (optimum between adsorbed surface $\mathrm{OH}$ groups and available holes at the surface), as reported in earlier work by our group. ${ }^{63}$ The presence of the anatase phase was confirmed by XRD analysis (see XRD pattern in Figure S1).

4EP belongs to the group of alkylphenols, which have been found in process water from the petrochemical industry, ${ }^{65}$ or as degradation product from alkylphenol ethoxylates (used in the chemical industry). ${ }^{66}$ These compounds are suspected to induce endocrine disruptive effects, and thus pose a health risk. ${ }^{67}$ In this study 4EP was used as model compound offering several experimental advantages, for example a moderate toxicity and an adequate water solubility. Moreover, the structure consists of three functional groups (benzene ring, alcohol group, alkyl chain) representing important functional groups of more complex compounds found in wastewater ${ }^{5,6}$ and is suitable to study the selectivity in reactions with chlorine. $^{68,69}$

PCD experiments were performed as described in the following: 4EP stock solution (approximately $50 \mathrm{mg} \cdot \mathrm{L}^{-1}$ ) was presaturated with air for $20 \mathrm{~min}$. The catalyst H600 [25( \pm 1 ) $\mathrm{mg}$ ], the required amount of salt and $50 \mathrm{~mL}$ stock solution were mixed in a quartz glass beaker, covered with a quartz glass lid and stirred $(350 \mathrm{rpm})$ in the dark for $30 \mathrm{~min}$ before the first sample was taken ( $0 \mathrm{~h}$ measurement). UV-irradiation of the suspension was achieved using a custom-made closed box reactor $^{64}$ equipped with eight Philips UV lamps (TL-D 18W $\mathrm{BLB}, \lambda_{\max } \approx 375 \mathrm{~nm}$, intensity $\approx 0.32 \mathrm{~mW} \cdot \mathrm{cm}^{-2}$ ). Any influence of UV light absorption by the salt solutions on the PCD rate was excluded (Figure S2). ${ }^{33}$ Liquid samples were taken after $0.5 \mathrm{~h}, 1 \mathrm{~h}, 2 \mathrm{~h}, 3 \mathrm{~h}, 4$ and $5 \mathrm{~h}$ of continuous illumination. Each time approximately $1.5 \mathrm{~mL}$ solution was taken. Afterward, the samples were filtered using a Phenex RC membrane filter $(0.2 \mu \mathrm{m}$; Phenomenex $)$, and analyzed by HPLC-UV and LC-MS.

Electrochemical Degradation. ECD of 4EP was performed in a custom-made single-compartment cell (see scheme in Figure S3). A platinized Ti plate electrode or BDD electrode (Magneto special anodes B.V; geometric surface area $3.14 \mathrm{~cm}^{2}$ ) was used to study the electrochemical degradation of 4EP. A Pt mesh and a $\mathrm{Ag} / \mathrm{AgCl}$ electrode (3 M NaCl, BASi) were used as a counter electrode and as a reference electrode, respectively. The reactor was filled with $70 \mathrm{~mL} 4 \mathrm{EP}$ stock solution (presaturated with air). Degradation experiments were carried out under galvanostatic conditions at $15 \mathrm{~mA} \cdot \mathrm{cm}^{-2}$ (VersaSTAT4 potentiostat, PAR or biologic SP-300/VMP3). The electrolyte was constantly stirred during the experiments. Sampling was performed as described for PCD. For high $\mathrm{NaCl}$ concentration, samples were also taken after $1 \mathrm{~min}, 2.5 \mathrm{~min}, 5$ min, $10 \mathrm{~min}, 15 \mathrm{~min}, 20 \mathrm{~min}$, and $30 \mathrm{~min}$. The cell was not purged with air, and the cathodic reaction is thus likely the formation of hydrogen. The surface area of the Pt gauze was significantly larger than the applied anode, and therefore the cathodic reaction was not limiting the degradation of hydrocarbons (see Figure S3).

To evaluate reactivity of 4EP with reactive chlorine species, $9.5 \mathrm{~mL}$ of $4 \mathrm{EP}$ stock solution $\left[50 \mathrm{mg} \cdot \mathrm{L}^{-1}\right]$ was mixed with sodium hypochlorite solution $(0.5 \mathrm{~mL}$, equal to approximately 

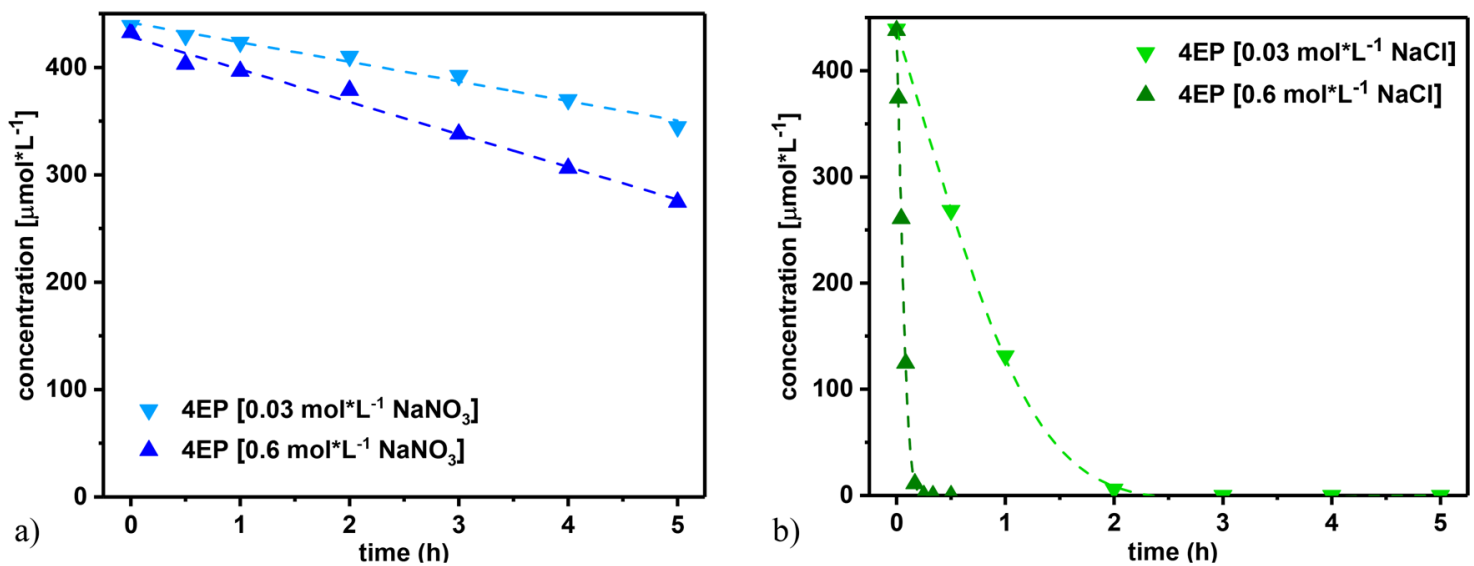

Figure 1. Electrochemical degradation of $4 \mathrm{EP}$ at various salt conditions: a) $0.03 \mathrm{~mol} \cdot \mathrm{L}^{-1} \mathrm{NaNO}_{3}$ (light blue), $0.6 \mathrm{~mol} \cdot \mathrm{L}^{-1} \mathrm{NaNO}_{3}$ (dark blue); and b) $0.03 \mathrm{~mol} \cdot \mathrm{L}^{-1} \mathrm{NaCl}$ (light green), $0.6 \mathrm{~mol} \cdot \mathrm{L}^{-1} \mathrm{NaCl}$ (dark green). ECD was performed at a Ti/Pt working electrode at constant current density of $15 \mathrm{~mA} \cdot \mathrm{cm}^{-2}$.

$20 \mathrm{mg} \cdot \mathrm{L}^{-1}$ free chlorine) and treated for $15 \mathrm{~min}$. Filtration was followed by LC-MS analysis.

Photoelectrochemical Degradation. PECD experiments were carried out in a custom-made Teflon based PEC-cell. The reactor was equipped with a thin film of $\mathrm{TiO}_{2}$ on a Ti-electrode (for the preparation see SI; geometric surface area $3.14 \mathrm{~cm}^{2}$ $\left.\left[\mathrm{TiO}_{2} / \mathrm{Ti}\right]\right)$ or $\mathrm{H} 600$ coated on FTO ([H600/FTO], 2.54 $\left.\mathrm{cm}^{2}\right]$ ) and a Pt-mesh counter electrode. The reactor was filled with the $4 \mathrm{EP}$ stock solution containing $0.03 \mathrm{~mol} \cdot \mathrm{L}^{-1} \mathrm{NaCl}$, and pretreated by purging air. Experiments were carried out under potentiostatic conditions at $0.1 \mathrm{~V}$ vs $\mathrm{Ag} / \mathrm{AgCl}$ reference electrode (3 M NaCl, BASi) using a potentiostat (VersaStat3, PAR or biologic SP-300). The electrolyte was constantly stirred and illuminated with a $365 \mathrm{~nm} \mathrm{LED}$ [for $\mathrm{TiO}_{2} / \mathrm{Ti}$ experiments] or $375 \mathrm{~nm}$ LED [for H600/FTO experiments] (Roithner Lasertechnik GmbH, APG2C1-365/375-E, $200 \mathrm{~mW}$ output power) placed in front of the glass window of the PECcell.

Analytical Methods. HPLC analysis was performed by a ThermoFisher Scientific Dionex Ultimate 3000 HPLC system equipped with a UV detector and a reversed phase Luna Omega polar C18 column $\left(3 \mu \mathrm{m}, 150 \times 2.1 \mathrm{~mm}^{2}\right.$, protected by a polar C18 security guard column (both Phenomenex)). The sample injection volume was $5 \mu \mathrm{L}$. The oven temperature was set to $30{ }^{\circ} \mathrm{C}$. A water ([A]; $0.1 \%$ formic acid) - acetonitrile $(0.1 \%$ formic acid) gradient system was used at a flow rate of $0.200 \mathrm{~mL} / \mathrm{min}$ and a total run time of $60 \mathrm{~min}$. (0 min 100\% A, $1 \min 100 \%$ A, $30 \min 50 \%$ A, 35 min 50\% A, $45 \min 5 \%$ A, 50 $\min 5 \% \mathrm{~A}, 55 \mathrm{~min} 100 \% \mathrm{~A}$, and $60 \mathrm{~min} 100 \% \mathrm{~A})$. For detection, UV absorption was measured at $276 \mathrm{~nm}$. For the quantification, an external standard calibration was applied (for more information see SI Figure S4 and Tables S1-S3).

For the identification of intermediates, a Bruker amaZon SL ion trap using electrospray ionization (conditions: capillary $4500 \mathrm{~V}$, end plate offset $500 \mathrm{~V}, 15$ psi nebulizer gas pressure $\left(\mathrm{N}_{2}\right), 8 \mathrm{~L} / \mathrm{min}$ dry gas flow $\left(\mathrm{N}_{2}\right), 200{ }^{\circ} \mathrm{C}$ dry gas temperature, scan between 50 to $1000 \mathrm{~m} / z)$ was coupled to the HPLC system. A divert-valve was used for salt separation. Ionization was performed in both positive and negative mode under alternating conditions using automatic fragmentation for datadependent acquisition of both MS and LC MS data.

Free chlorine $\left((\mathrm{FC})\right.$; total concentration of $\mathrm{Cl}_{2}+\mathrm{HOCl}+$ $\left.\mathrm{OCl}^{-}\right)$measurements were performed in adaption of the EPADPD method 330.5, using a Hanna Instruments free chlorine test kit (HI93701) and photometer (HI83099) for a concentration range of 0.00 to $2.50 \mathrm{mg} \cdot \mathrm{L}^{-1}$ [accuracy \pm 0.03 $\left.\mathrm{mg} \cdot \mathrm{L}^{-1}\right]$. For higher free chlorine concentrations a Hanna Instruments test kit (HI95771) and photometer (HI96771) were used [accuracy $\pm 2 \mathrm{mg} \cdot \mathrm{L}^{-1}$ ].

Non-purgeable organic carbon (NPOC) content was determined with a SHIMADZU total organic carbon analyzer, TOC-L CPH/CPN (see SI for more information)

\section{RESULTS AND DISCUSSION}

Electrochemical Degradation (ECD) of 4EP. Degradation curves of $4 \mathrm{EP}$ obtained for ECD at various salt conditions $\left(\mathrm{NaNO}_{3}\right.$ or $\mathrm{NaCl}$ containing electrolytes), at constant current density of $j=15 \mathrm{~mA} \cdot \mathrm{cm}^{-2}$, are shown in Figure 1. A linear degradation behavior was obtained for both $\mathrm{NaNO}_{3}$ concentrations (Figure 1a), and zero-order kinetic constants can be estimated to be $\sim 20 \mu \mathrm{mol} \mathrm{L}{ }^{-1} \cdot \mathrm{h}^{-1}$ and $30 \mu \mathrm{mol} \mathrm{L}{ }^{-1} \cdot \mathrm{h}^{-1}$ for the low or high salt concentrations, respectively (voltagetime curves are shown in Figure S5 and quantified numbers are presented in Table S4).

In contrast to $\mathrm{NaNO}_{3}$, which cannot be oxidized to reactive radicals, the degradation of 4EP in chloride-containing media proceeded much faster (Figure 1b). Again assuming linear regression (zero-order), constants of $\sim 300 \mu \mathrm{mol} \mathrm{L}{ }^{-1} \cdot \mathrm{h}^{-1}$ and $\sim 3750 \mu \mathrm{mol} \mathrm{L}{ }^{-1} \cdot \mathrm{h}^{-1}$ can be computed for low and high $\mathrm{NaCl}$ concentration, respectively. The fast 4EP degradation in the $\mathrm{NaCl}$ experiments can be explained by chlorine mediated electrochemical oxidation, where free chlorine (i.e., hypochlorite) and chlorine radicals support the degradation of organic pollutants. ${ }^{11-15}$ In agreement with this hypothesis, the measured concentrations of FC amounted to $0.95 \mathrm{mg} \cdot \mathrm{L}^{-1}$ (after $5 \mathrm{~h}$ at $0.03 \mathrm{~mol} \cdot \mathrm{L}^{-1} \mathrm{NaCl}$ ) and $111 \mathrm{mg} \cdot \mathrm{L}^{-1}$ (after $30 \mathrm{~min}$ at $\left.0.6 \mathrm{~mol} \cdot \mathrm{L}^{-1}\right)$.

Theoretically an electric charge of 110 Coulomb is required for full mineralization of 4EP, corresponding to approximately $40 \mathrm{~min}$ of continuous treatment at the applied current density of $j=15 \mathrm{~mA} \cdot \mathrm{cm}^{-2}$.

The presence of RCS was found to induce the formation of undesired chlorinated organic intermediates and byproducts $(\mathrm{RCl})$, in agreement with literature. ${ }^{12,16-20} \mathrm{LC}-\mathrm{MS}$ analysis revealed the formation of 2-chloro-4-ethylphenol (2C4EP) and 2,6-dichloro-4-ethylphenol (26DC4EP), see Figure 2. The same intermediates were also formed during chemical chlorination of 4EP with sodium hypochlorite solution (20 
<smiles>CCCCCCCc1cc(O)ccc1CC</smiles>

4EP

II) 26DC4EP
Figure 2. Reaction path of 4EP with RCS (mainly hypochlorite) during ECD at $15 \mathrm{~mA} \cdot \mathrm{cm}^{-2}$ at a Ti/Pt electrode or BDD electrode in $\mathrm{NaCl}$ media $\left(0.03 \mathrm{~mol} \cdot \mathrm{L}^{-1} \mathrm{NaCl}\right.$ and $\left.0.6 \mathrm{~mol} \cdot \mathrm{L}^{-1} \mathrm{NaCl}\right)$. 2-Chloro-4ethylphenol (2C4EP) and 2,6-dichloro-4-ethylphenol (26DC4EP) were identified as the main aromatic intermediates.

$\mathrm{mg} \cdot \mathrm{L}^{-1} \mathrm{FC}$ ), showing that conversion of $4 \mathrm{EP}$ in saline conditions resembles chemical chlorination. The chlorination of the aromatic ring at the ortho position is directed by the adjacent $\mathrm{OH}$-group and is a typical reaction of phenolic compounds with electrophilic oxidants. ${ }^{70,71}$ Furthermore, the identified intermediates are in good agreement with other literature reports on phenol and bisphenol conversion, using degradation at $\mathrm{BDD}$ electrodes at low salt concentrations ${ }^{16,18,19}$ and the chemical chlorination of methylphenols. ${ }^{72}$

In order to understand the subsequent degradation process of the two intermediates, the concentration vs time profiles were determined (Figure 3). Obviously, 4EP is converted into 2C4EP almost instantaneously. For the low $\mathrm{NaCl}$ concentration (Figure 3a) a maximum in 2C4EP concentration is obtained after $1-1.5 \mathrm{~h}$ of treatment time, with 2C4EP already exceeding the concentration of 4EP. The measured concentration of $149 \mu \mathrm{mol} \mathrm{L}{ }^{-1}\left[23.3 \mathrm{mg} \cdot \mathrm{L}^{-1}\right]$ of $2 \mathrm{C} 4 \mathrm{EP}$ corresponds to a molar fraction of $34 \%$ relative to the initial molar concentration of 4EP (for more information see also Figure S6).

26DC4EP is already formed during accumulation of 2C4EP indicating a continuous consecutive transformation of 4EP into 2C4EP and 26DC4EP (Figure 2). Again these results are in agreement with the chemical chlorination of phenol $^{70}$ and recent studies on phenol degradation at a BDD electrode in solutions of low salinity. ${ }^{16}$ A concentration maximum of 45 $\mu \mathrm{mol} \mathrm{L}{ }^{-1}\left[8.6 \mathrm{mg} \cdot \mathrm{L}^{-1}\right]$ in $26 \mathrm{DC} 4 \mathrm{EP}$, corresponding to a molar fraction of $10 \%$ relative to the initial molar concentration of $4 \mathrm{EP}$, was obtained after $2 \mathrm{~h}$. It took as long as $4 \mathrm{~h}$ of ECD at low $\mathrm{NaCl}$ concentration, to remove both intermediates completely from solution (below the limit of detection (LOD), see Table S3 for more information).

Similar concentration profiles were obtained for the high salt conditions, however within shorter reaction times (Figure $3 b$ ). Already after $5 \mathrm{~min}, 2 \mathrm{C} 4 \mathrm{EP}$ reached its maximum concentration $\left(90 \mu \mathrm{mol} \mathrm{L}{ }^{-1}\left[14.1 \mathrm{mg} \cdot \mathrm{L}^{-1}\right]\right.$, corresponding to $21 \mathrm{~mol}$ $\%$ of the initial 4EP concentration). 26DC4EP reached its maximum concentration after $10 \mathrm{~min}\left(30 \mu \mathrm{mol} \mathrm{L}{ }^{-1}[5.7 \mathrm{mg}\right.$. $\mathrm{L}^{-1}$ ], corresponding to $7 \mathrm{~mol} \%$ of the initial 4EP concentration). After $20 \mathrm{~min}$ of treatment both intermediates were removed from solution. For comparison, the performance of a BDD electrode is shown in Figure $3 \mathrm{c}$ and d) for the low
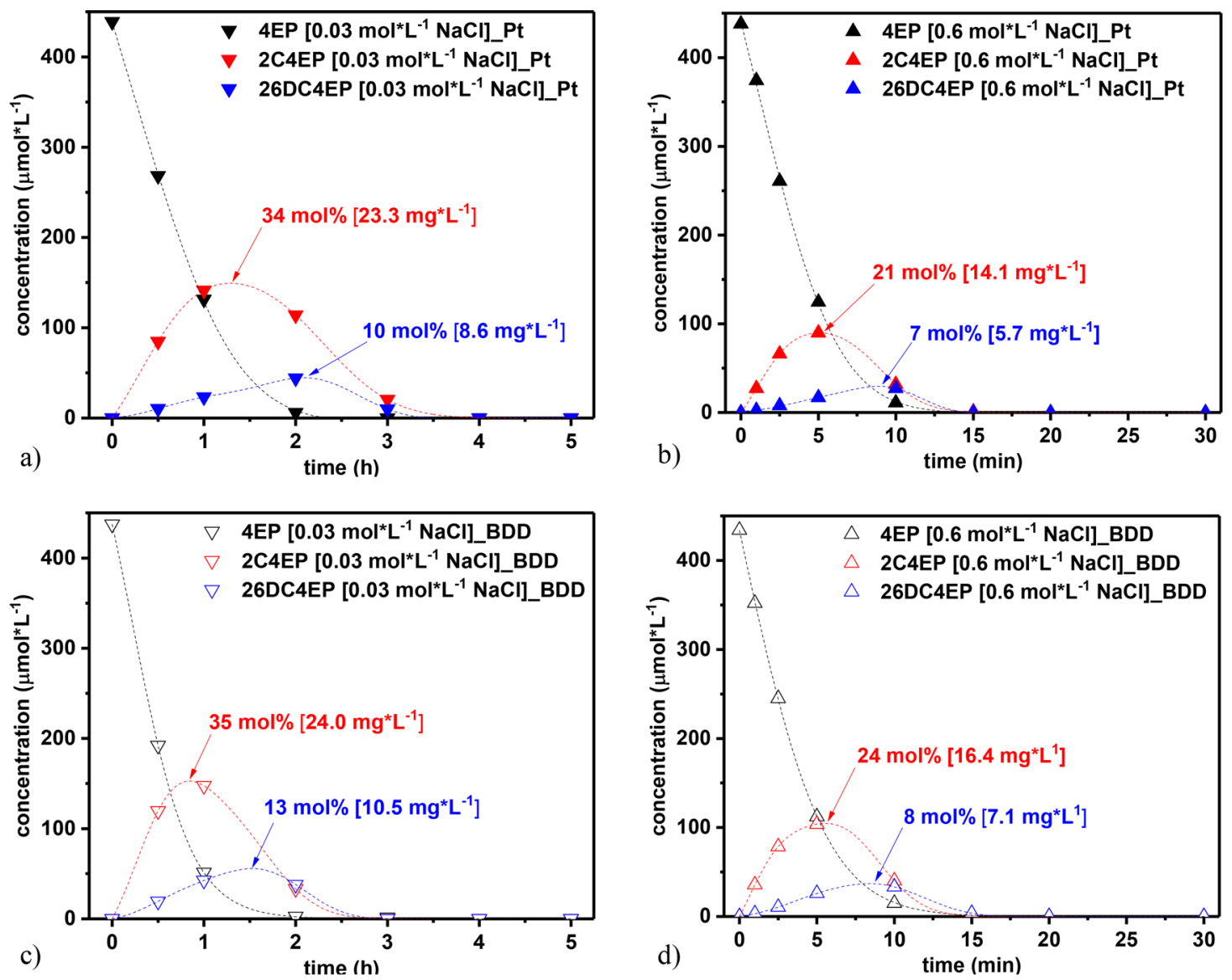

Figure 3. Formation and degradation of 2C4EP (red) and 26DC4EP (blue) formed during ECD of 4EP (black) in $0.03 \mathrm{~mol} \cdot \mathrm{L}^{-1} \mathrm{NaCl}(\mathrm{a}$ and c) and $0.6 \mathrm{~mol} \cdot \mathrm{L}^{-1} \mathrm{NaCl}$ solution ( $\mathrm{b}$ and $\mathrm{d}$ ) using $\mathrm{Ti} / \mathrm{Pt}(\mathrm{a}$ and $\mathrm{b}$ ) or BDD electrode ( $\mathrm{c}$ and $\mathrm{d}$ ). 
and high $\mathrm{NaCl}$ concentration. While small changes in the kinetic curves of the degradation of 4EP and formation of chlorinated intermediates are present, generally both electrodes perform similarly under the studied conditions.

The results suggest that significant amounts of the same mono- and dichlorinated intermediates were formed and builtup in the solution for both $\mathrm{NaCl}$ concentrations and both electrode types. Although the apparent removal of the starting compound 4EP is fast (compared to $\mathrm{NaNO}_{3}$ ) a large fraction of 4EP is directly converted into chlorinated compounds in a consecutive reaction path (Figure 2). Interestingly for the higher salt concentration less 2C4EP and 26DC4EP were measured, however the higher FC concentration led to a faster removal rate which most likely suppresses more accumulation of these intermediates.

In addition to the two identified intermediates various other chlorinated compounds were detected by MS. While identification of their structure exceeds the scope of this work, it is interesting to note that the degradation of these intermediates is significantly delayed (Figure S7). The degradation pattern indicates that these compounds are obtained by additional reactions of the two main intermediates, 2C4EP and 26DC4EP. Hydroxylation ${ }^{72,73}$ and subsequent ring opening ${ }^{73,74}$ might cause the formation of several other intermediates. In addition, dimerization has been proposed for chemical chlorination of methylphenols leading to polychlorinated methylphenoxymethylphenols, ${ }^{72}$ and the formation of polychlorinated phenol oligomers was observed during ECD of phenol and 2-chlorophenol. ${ }^{74,75}$ Therefore, it is likely that the detected intermediates are congeners of the reported polychlorinated phenol oligomers.

The formation of small chlorinated end products such as chloromethanes ${ }^{17,76}$ and chlorinated acetic acids ${ }^{17}$ has been reported for ECD in saline water, and formation likely occurs 4-5 $\mathrm{h}$ after the start of our experiment. In order to analyze the residual organic content after oxidation of 4EP, non-purgeable organic carbon (NPOC) measurements were performed. The NPOC values (Figure 4) clearly indicate that large amounts, between $64 \%$ to $86 \%$ of the initial organic carbon, were still present. Even after extended treatment times of $5 \mathrm{~h}$ (high salinity) only $23 \%$ of organic carbon was effectively removed.

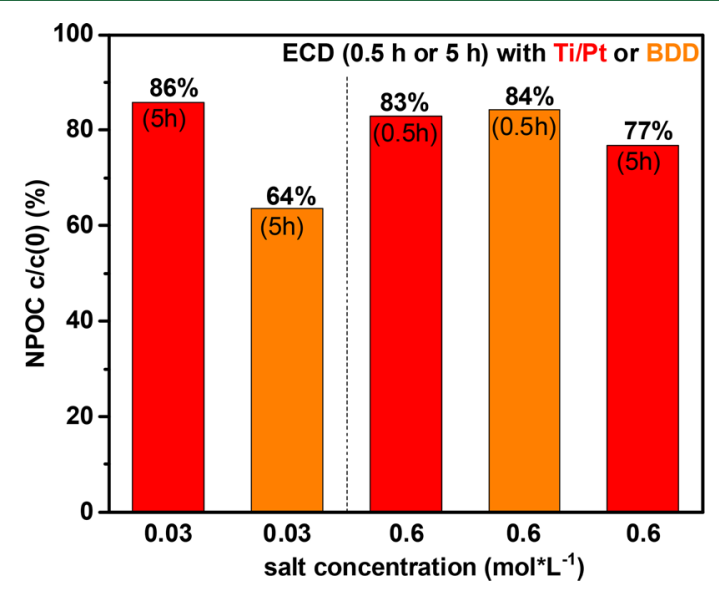

Figure 4. Non-purgeable organic carbon (NPOC) measurements of treated waters after ECD of 4EP at constant current conditions (15 $\mathrm{mA} \cdot \mathrm{cm}^{-2}$ ) at a Ti/Pt or BDD electrode in $\mathrm{NaCl}$ media. NPOC values were measured after $5 \mathrm{~h} \mathrm{ECD}$ in $0.03 \mathrm{~mol} \cdot \mathrm{L}^{-1} \mathrm{NaCl}$ media and after $30 \mathrm{~min}$ and $5 \mathrm{~h}$ for $0.6 \mathrm{~mol} \cdot \mathrm{L}^{-1} \mathrm{NaCl}$.
These nonvolatile compounds are most probably low molecular weight organic compounds such as organic acids, which have been detected after aromatic ring cleavage during ECD in $\mathrm{NaCl}$ solution $^{74}$ and might also consist of chlorinated derivates such as chlorinated organic acids. ${ }^{17}$

The experimental observations highlight a major bottleneck of electrochemical AOP techniques. Although ECD in saline conditions appeared to be efficient, especially compared to inert salt conditions, undesirable (poly)chlorinated aromatic intermediates were formed for both electrodes that require long treatment times. Moreover, the degradation of 4EP and (chlorinated) intermediates on a $\mathrm{Ti} / \mathrm{Pt}$ electrode led only to a breakdown of the aromatic compounds, and the total removal rate of organic carbon was quite poor. Only for BDD at low salt concentration slightly higher NPOC removal was achieved, most likely due to an increased contribution of generated $\mathrm{OH}$ radicals. Still, $64 \%$ of the NPOC remained after $5 \mathrm{~h}$ treatment and significant amounts of $\mathrm{RCl}$ were formed (Figure 3), leading to the conclusion that for both electrodes chlorination is the main degradation pathway under the studied conditions, which is in agreement with a recent report of high faradaic efficiency for chloride oxidation on BDD electrodes. ${ }^{77}$

Photocatalytic Degradation (PCD) of 4EP. The photocatalytic degradation of 4EP at various salt conditions is shown in Figure 5. Using a pseudo first order approximation, implying

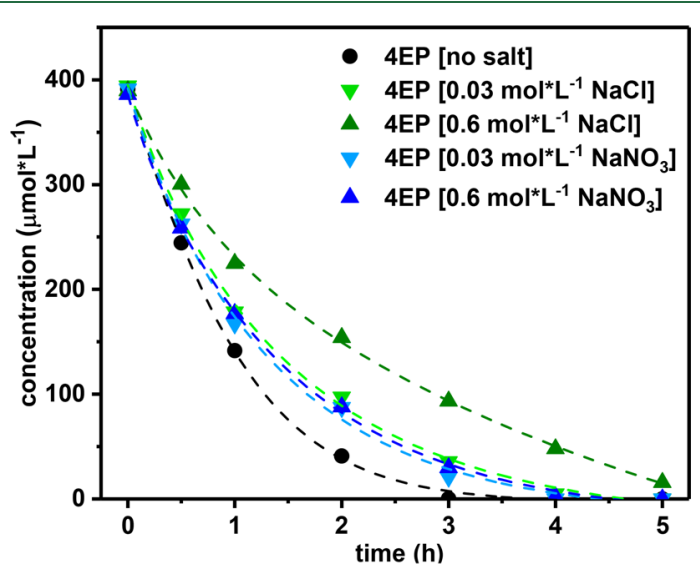

Figure 5. Photocatalytic degradation of $4 \mathrm{EP}$ at various salt conditions: no salt (black curve), $0.03 \mathrm{~mol} \cdot \mathrm{L}^{-1} \mathrm{NaNO}_{3}$ (light blue), $0.6 \mathrm{~mol} \cdot \mathrm{L}^{-1}$ $\mathrm{NaNO}_{3}$ (dark blue), $0.03 \mathrm{~mol} \cdot \mathrm{L}^{-1} \mathrm{NaCl}$ (light green), and $0.6 \mathrm{~mol}$. $\mathrm{L}^{-1} \mathrm{NaCl}$ (dark green). PCD was performed under $375 \mathrm{~nm}$ illumination in a $\mathrm{TiO}_{2}(\mathrm{H} 600)$ slurry $\left[0.5 \mathrm{~g} \cdot \mathrm{L}^{-1}\right]$.

surface mediated conversion is dominating, rate constants are estimated to be $1.13 \mathrm{~h}^{-1}$ in the absence of salt, $0.8 \mathrm{~h}^{-1}$ in the presence of $\mathrm{NaNO}_{3}$ (high and low concentration), and $0.8 \mathrm{~h}^{-1}$ and $0.5 \mathrm{~h}^{-1}$ for low and high concentration of $\mathrm{NaCl}$. To compare the rates to ECD, initial rates can be calculated (using the initial concentration of $410 \mu \mathrm{mol} \mathrm{L} \mathrm{L}^{-1}\left[50 \mathrm{mg} \cdot \mathrm{L}^{-1}\right]$ ) to be $\sim 330 \mu \mathrm{mol} \mathrm{L}{ }^{-1} \cdot \mathrm{h}^{-1}$ or $\sim 205 \mu \mathrm{mol} \mathrm{L}{ }^{-1} \cdot \mathrm{h}^{-1}$ for the low or high $\mathrm{NaCl}$ concentration, respectively. At low $\mathrm{NaCl}$ concentration, the rates of ECD and PCD are comparable, but in contrast to $\mathrm{ECD}$, addition of $\mathrm{NaCl}$ to high concentration, had a negative effect on the degradation rates of the parent compound 4EP, leading to an order of magnitude difference under these conditions $\left(\sim 3750 \mu \mathrm{mol} \mathrm{L}{ }^{-1} \cdot \mathrm{h}^{-1}\right.$ vs $205 \mu \mathrm{mol} \mathrm{L} \mathrm{L}^{-1} \cdot \mathrm{h}^{-1}$ for respectively $\mathrm{ECD}$ and $\mathrm{PCD}$ ). The inhibiting effect of $\mathrm{NaCl}$ is in agreement with observations reported for PCD of phenol. ${ }^{38}$ Since the inhibitation at $0.6 \mathrm{~mol} \cdot \mathrm{L}^{-1} \mathrm{NaCl}$ is clearly more 
<smiles>CCc1ccc(O)c(O)c1</smiles>

a)

(4)

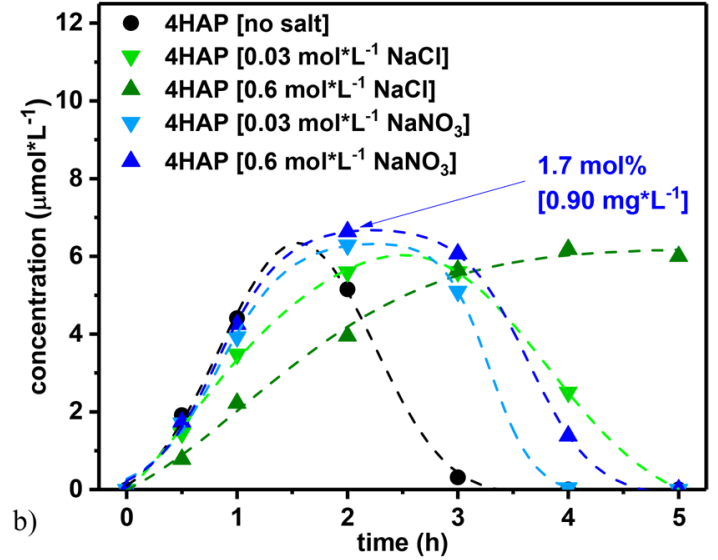

Figure 6. a) Chemical structures of the identified aromatic intermediates during PCD of 4EP observed for all studied salt conditions (no salt, 0.03 $\mathrm{mol} \cdot \mathrm{L}^{-1} \mathrm{NaNO}_{3}, 0.6 \mathrm{~mol} \cdot \mathrm{L}^{-1} \mathrm{NaNO}_{3}, 0.03 \mathrm{~mol} \cdot \mathrm{L}^{-1} \mathrm{NaCl}, 0.6 \mathrm{~mol} \cdot \mathrm{L}^{-1} \mathrm{NaCl}$ : (1) 1-(4-hydroxyphenyl)ethanol, (2) 4-hydroxybenzaldehyde, (3) 4hydroxyacetophenone, (4) 4-ethylresorcinol, and (5) 4-ethylcatechol. b) Formation and degradation of intermediate (3) 4-hydroxyacetophenone during PCD of 4EP at various salt conditions: no salt (black curve), $0.03 \mathrm{~mol} \cdot \mathrm{L}^{-1} \mathrm{NaNO}_{3}$ (light blue), $0.6 \mathrm{~mol} \cdot \mathrm{L}^{-1} \mathrm{NaNO}_{3}$ (dark blue), $0.03 \mathrm{~mol}$. $\mathrm{L}^{-1} \mathrm{NaCl}$ (light green), and $0.6 \mathrm{~mol} \cdot \mathrm{L}^{-1} \mathrm{NaCl}$ (dark green).

significant than at $0.6 \mathrm{~mol} \cdot \mathrm{L}^{-1} \mathrm{NaNO}_{3}$, the inhibition is mainly attributed to the presence of $\mathrm{Cl}^{-}$. ${ }^{24}$

While the exact reason for the negative effect of anions is still under debate, blocking of active surface sites ${ }^{25,28-32}$ appears unlikely as the main explanation. Considering a point of zero charge (PZC) for $\mathrm{TiO}_{2}$ between 5 to $6,^{78}$ the $\mathrm{TiO}_{2}$ particle surface charge in this study is neutral as measurements were performed at circumneutral conditions. Moreover, under illumination the buildup of a negative surface charge has been observed for $\mathrm{TiO}_{2}$ particles $(\mathrm{pH}>\text { isoelectric point })^{79,80}$ hindering competitive adsorption or blocking of active surface sites by chloride anions. In the case of chloride adsorption on the $\mathrm{TiO}_{2}$ particles $(\mathrm{pH}<\mathrm{PZC}$, for example possible due to a $\mathrm{pH}$ drop during PCD because of dissolved $\mathrm{CO}_{2}$ produced during degradation; see also Figure S8) the oxidation of chloride ions, by either photogenerated valence band holes and/or hydroxyl radicals becomes likely. ${ }^{24-27,35-37,39,40,57}$ As a consequence RCS formation would occur, supporting the 4EP removal as observed in ECD. However, our results indicate that the degradation pathways of 4EP during PCD and ECD are different and RCS likely do not contribute to PCD. Thus, just blocking of active sites by $\mathrm{Cl}^{-}$cannot fully explain the observations. In order to verify this conclusion we analyzed the intermediates formed during (PCD).

Unlike in the case of ECD, chlorinated intermediates were identified only in extremely low quantities, and HPLC analysis showed the following aromatic intermediates in significantly larger quantities: (1) 1-(4-hydroxyphenyl)ethanol, (2) 4hydroxybenzaldehyde, (3) 4-hydroxyacetophenone, (4) 4ethylresorcinol, and (5) 4-ethylcatechol (Figure 6a; more information SI Table S1). Thus, the model compound 4EP is oxidized at least at three carbon atoms during PCD, which is typical for nonselective radical reactions (i.e., by $\left.{ }^{\bullet} \mathrm{OH}\right)$. The formation of the isomer 2-(4-hydroxyphenyl)ethanol could not be revealed due to overlapping retention times with (1) (SI Table S1). However, the increased stability of secondary alkyl radicals favors the formation of intermediate (1) and its subsequent oxidation product (3). Therefore, the formation of 2-(4-Hydroxyphenyl)ethanol is of minor contribution during PCD of 4EP. The same intermediates were detected for all PCD conditions. The nonselective radical reaction pathway is also in good agreement with other reports, e.g., for PCD of ethylbenzene, $^{81}$ phenol $^{37,42,82}$ or p-cresol, $^{83}$ confirming that RCS are insignificantly involved in the degradation path.

For the most abundant intermediate (3), its formation and degradation at different salt conditions is shown in Figure 6b. At high $\mathrm{NaCl}$ concentration a pronounced inhibition of formation and subsequent degradation was observed, whereas the influence of $\mathrm{NaNO}_{3}$ or low $\mathrm{NaCl}$ concentration is less. The observations are related to the 4EP removal, where the strongly inhibited 4EP degradation explains the delayed formation of (3) at high $\mathrm{NaCl}$ concentration. This is in agreement with reports for PCD of phenol. ${ }^{38}$

As 2C4EP and 26DC4EP were detected as main chlorinated intermediates in ECD the obtained chromatograms were thoroughly analyzed in PCD. Only for high salt concentration small amounts of 2C4EP could be measured and quantified (Figure 7). Similarly to ECD measurements, formation of

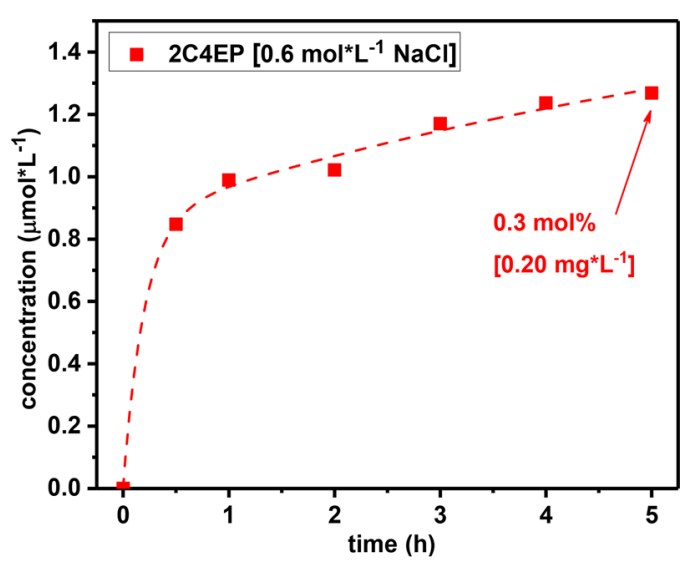

Figure 7. Formation of the monochlorinated intermediate 2C4EP during PCD of $4 \mathrm{EP}$ in $0.6 \mathrm{~mol} \cdot \mathrm{L}^{-1} \mathrm{NaCl}$ solution.

2C4EP occurs immediately, slowly accumulates in the reactor, and its degradation is strongly retarded in agreement with intermediate (3) monitored during PCD at high saline conditions (see Figure $6 \mathrm{~b}$ ). If at all formed, then the concentration of 26DC4EP remained below the LOD.

Again FC concentrations were determined. For low $\mathrm{NaCl}$ concentrations the measured values are below the limit of 
accuracy; for high $\mathrm{NaCl}$ concentrations only small amounts of FC could be detected $\left[0.15 \mathrm{mg} \cdot \mathrm{L}^{-1}\right]$. This shows that PCD is hardly mediated by FC species, in agreement with the low quantities of chlorinated intermediates.

In general the oxidation of chloride by scavenging $\mathrm{OH}$ radicals is not favored at the conditions of this study. ${ }^{45,52,84}$ Zhang et al. concluded chloride being a poor hydroxyl radical scavenger at circumneutral to alkaline conditions, because the equilibrium of the reaction is favored for the reverse reaction to $\mathrm{Cl}^{-}$and ${ }^{\bullet} \mathrm{OH}(>99.98 \%){ }^{52}$ The absence of $\mathrm{FC}$ for smaller $\mathrm{Cl}^{-}$concentrations is also in agreement with findings reported by Krivec et al., ${ }^{32}$ who did not detect $\mathrm{Cl}^{\bullet}$ radicals. For higher $\mathrm{NaCl}$ concentrations the results match the observations by Azevedo et al. $^{38}$ who reported small amounts of 4chlorophenol (not quantified) formed during phenol PCD at high salt concentrations. Anyway, the results indicate that chloride is barely oxidized during PCD, and formation of RCS is negligible.

As for the ECD experiments, the overall removal of organic carbon during the PCD treatment was estimated by determination of the NPOC content. Results obtained after $5 \mathrm{~h}$ of PCD in saline water are shown in Figure 8. In the

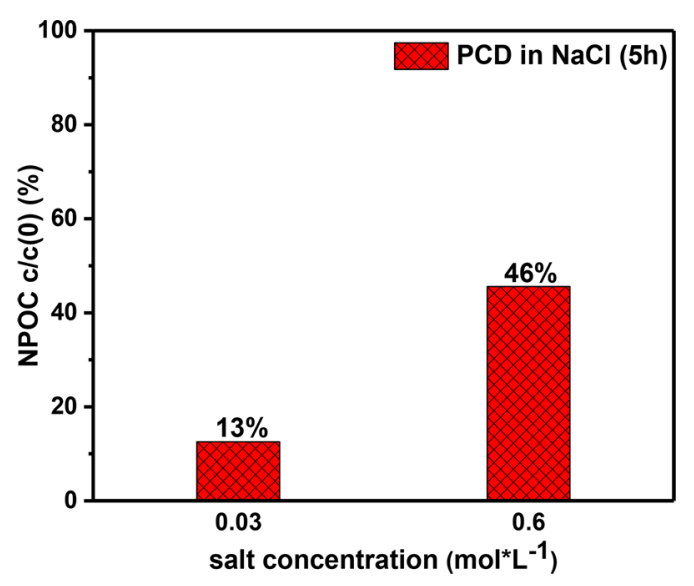

Figure 8. Non-purgeable organic carbon (NPOC) measurements of treated waters after $5 \mathrm{~h} \mathrm{PCD}$ of $4 \mathrm{EP}$ in $0.03 \mathrm{~mol} \cdot \mathrm{L}^{-1} \mathrm{NaCl}$ and 0.6 $\mathrm{mol} \cdot \mathrm{L}^{-1} \mathrm{NaCl}$.

absence of any salt NPOC was below the LOD. This is in agreement with the non-affected 4EP and intermediate removal (compared to salt containing solutions) and indicates a complete removal of the organic carbon within the duration of the PCD experiments. For the low and high $\mathrm{NaCl}$ concentration, residual NPOC remained in the solution in agreement with the delay in 4EP degradation. For example, although 4EP and the main intermediate (3) were removed after $5 \mathrm{~h}$ treatment in $0.03 \mathrm{~mol} \cdot \mathrm{L}^{-1} \mathrm{NaCl}$ solutions, NPOC of $13 \%$ was measured. Since the UV chromatogram did not show any significant peaks after $5 \mathrm{~h}$ of PCD, the residual organic carbon is most likely due to compounds arising from ringopening reactions, such as short chain aliphatic compounds and carboxylic acids. ${ }^{82,85,86}$ At high $\mathrm{NaCl}$ concentrations, a residual NPOC of $46 \%$ remained. Calculated photonic efficiencies of PCD experiments for the various salt conditions are shown in Table S5 and an estimation of the energy consumption compared to ECD experiments is shown in Table S6. For the applied conditions the energy consumption of the PCD treatment was approximately between 1 and 2 orders of magnitude higher compared to the ECD; however, it is important to note that the applied reactors were not optimized for energy consumption, and the applied light sources have low efficiency for illumination of the photocatalytic slurry (less than 1\%). Although ECD thus seems to appear beneficial in terms of consumed energy per $\mathrm{kg}$ removed non purgeable organic carbon (NPOC), degradation of 4EP by PCD leads to significantly smaller NPOC than ECD at comparable rate of 4EP conversion (low $\mathrm{NaCl}$ concentration). Moreover, the concentration of chlorinated intermediates formed during PCD is significantly lower (for low and high $\mathrm{NaCl}$ concentration) compared to ECD, thus photocatalysis appears to be the preferred method for application, in particular if illumination efficiency and reactor design are optimized.

Finally, photoelectrochemical degradation (PECD), a hybrid technology, was studied. The experiments were performed with a $\mathrm{TiO}_{2} / \mathrm{Ti}$ electrode at an applied anodic bias of $0.1 \mathrm{~V}$ vs $\mathrm{Ag} / \mathrm{AgCl}$ irradiated with UVA light (see Figure S9 for more information). In recent reports Zanoni et al. showed already that oxidation of chloride to $\mathrm{FC}$ at $\mathrm{TiO}_{2}$ photoelectrodes occurs $^{87}$ and the generation of RCS has been proposed to assist the PECD of organic compounds. ${ }^{46,57,61,88}$ Still, reports discussing the formation of intermediates are scarce. ${ }^{50,89}$ After 15 min of irradiation at low $\mathrm{NaCl}$ concentration, $92 \%$ of $4 \mathrm{EP}$ was removed and an intensive formation of RCS was observed (as detected by FC $\left[27 \mathrm{mg} \cdot \mathrm{L}^{-1}\right]$ ). The HPLC analysis (Figure 9) revealed significant amounts of the same intermediates, as

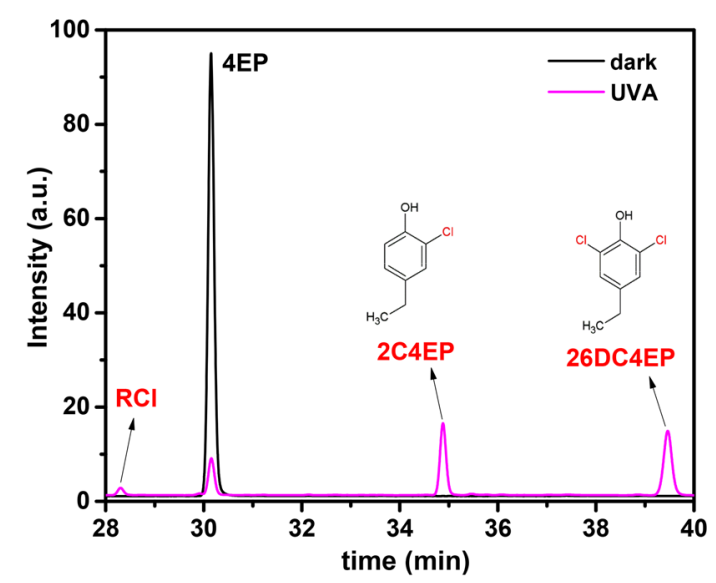

Figure 9. HPLC chromatogram obtained after $15 \mathrm{~min}$ PECD of 4EP in $0.03 \mathrm{~mol} \cdot \mathrm{L}^{-1} \mathrm{NaCl}$ solution using a $\mathrm{TiO}_{2} / \mathrm{Ti}$ electrode with 0.1 $\mathrm{V}_{[\mathrm{vs} \mathrm{Ag} / \mathrm{AgCl}]}$ bias and $365 \mathrm{~nm} \mathrm{UV} \mathrm{light.} \mathrm{The} \mathrm{majority} \mathrm{of} \mathrm{4EP} \mathrm{was}$ removed and transformed into significant amounts of the monochlorinated 2C4EP and dichlorinated 26DC4EP, similar as observed during ECD experiments.

observed during ECD $\left(57 \mu \mathrm{mol} \mathrm{L}{ }^{-1}\left[9 \mathrm{mg} \cdot \mathrm{L}^{-1}\right] 2 \mathrm{C} 4 \mathrm{EP}\right.$ and 89 $\left.\mu \mathrm{mol} \mathrm{L}{ }^{-1}\left[17 \mathrm{mg} \cdot \mathrm{L}^{-1}\right] 26 \mathrm{DC} 4 \mathrm{EP}\right)$. Interestingly, without additional bias (resembling PCD conditions) intermediate (3) was observed as main intermediate and the formation of chlorinated compounds was excluded (Figure S10). Thus, the 4EP reaction pathway can be easily modified by the applied bias. The blank experiment (PECD in dark at $0.1 \mathrm{~V}$ vs $\mathrm{Ag}$ / $\mathrm{AgCl}$ ) did not lead to any photocurrent, RCS formation, or 4EP degradation (Figure S11), because the applied potential was below any relevant standard redox potential (e.g $1.36 \mathrm{~V}$ vs SHE for chlorine evolution or $2.8 \mathrm{~V}$ vs SHE for $\bullet \mathrm{OH}$ generation). To verify the observations and exclude a particular effect of the applied $\mathrm{TiO}_{2}, \mathrm{PECD}$ experiments were conducted 
with the H600 photocatalyst coated on FTO glass, showing similar trends (see Table S7).

The effect of an applied anodic bias can be explained by the following: In a photocatalytic approach charge carrier (electrons and holes) are usually generated close to the particle surface and physical separation of reduction and oxidation sites is hardly achieved on the nanoscale. Thus, oxidation and reduction occur in close proximity and the recombination of oxidized chloride with photogenerated $\mathrm{CB}$ electrons is likely. This surface-charge recombination mechanism (quenching of photogenerated charge carriers by chloride ions $)^{34}$ is effectively suppressed when an anodic bias is applied, e.g., in PECD experiments. Upon biasing the electrode photogenerated conduction band $(\mathrm{CB})$ electrons from the $\mathrm{TiO}_{2}$ surface are pulled toward the back contact and in contrast to PCD, reduction of Cl-radicals by available $\mathrm{CB}$ electrons is unfeasible. Therefore, pronounced RCS generation could be observed during PECD, leading to a distinctive formation of $\mathrm{RCl}$. In addition, the Coulombic repulsion between the $\mathrm{TiO}_{2}$ surface and chloride ions ${ }^{90}$ is lowered upon polarization of the $\mathrm{TiO}_{2}$ surface. ${ }^{50}$ This facilitates the adsorption of $\mathrm{Cl}^{-}$on the positively charged $\mathrm{TiO}_{2}$ surface allowing for chloride oxidation (RCS formation) and subsequent formation of $\mathrm{RCl}$.

Combining all information, it is evident that although not all of the organic carbon could be removed during PCD, the removal of organic carbon was more effective in the purely light-driven approach compared to ECD (under the conditions applied in this study). Especially, the significantly smaller formation of RCS and RCl intermediates during PCD is of importance. During ECD in saline media 4EP was mainly removed by conversion into (polychlorinated) compounds and only small amounts of 4EP could be completely mineralized. In contrast, during PCD only for high $\mathrm{NaCl}$ concentrations minor formation of monochlorinated 2C4EP could be detected. The measured 2C4EP concentration during ECD at $0.6 \mathrm{~mol} \cdot \mathrm{L}^{-1}$ was nearly 2 orders of magnitude higher than that detected after $5 \mathrm{~h}$ of PCD. The difference in the AOP techniques is likely governed by a surface-charge recombination mechanism in PCD, which suppresses FC and $\mathrm{RCl}$ formation. Overall, the formation of chlorinated intermediates in both AOP technologies is important for consideration of practical wastewater treatment applications.

\section{ASSOCIATED CONTENT}

\section{S Supporting Information}

The Supporting Information is available free of charge on the ACS Publications website at DOI: 10.1021/acs.est.9b01244.

Synthesis of 1-(4-hydroxyphenyl)ethanol; NPOC measurements; synthesis $\mathrm{TiO}_{2}$ photoelectrodes; 4EP and identified intermediates; coefficient of determination (calibration); limit of detection; $i R$ drop corrected potentials; XRD of pretreated photocatalyst; UV transmission of salt solutions; scheme of electrochemical cell; calibration curves; potential-time curves; ECD intermediates (molar fraction); ECD additional intermediate; PCD pH development; PCD photonic efficiencies; energy consumption; PECD linear sweep voltammograms; PECD without bias (chromatogram); PECD in dark (photocurrent); and PECD intermediates with H600/FTO electrode (PDF)

\section{AUTHOR INFORMATION}

\section{Corresponding Author}

*Phone:+31534893890; e-mail: g.mul@utwente.nl . ORCID

Bastian Mei: 0000-0002-3973-9254

Guido Mul: 0000-0001-5898-6384

Notes

The authors declare no competing financial interest.

\section{ACKNOWLEDGMENTS}

This research is financed by The Netherlands Organisation for Scientific Research (NWO), which is partly funded by the Ministry of Economic Affairs and Climate Policy, and cofinanced by The Netherlands Ministry of Infrastructure and Water Management and partners of the Dutch Water Nexus consortium (project number 14301). Dyllian Huijgens is acknowledged for PCD experiments. Erna Fränzel-Luiten and Robert Meijer are acknowledged for technical support.

\section{REFERENCES}

(1) WWAP (United Nations World Water Assessment Programme). The United Nations World Development Report 2015: Water for a Sustainalbe World; UNESCO: Paris, 2015.

(2) Smalley, R. E. Future Global Energy Prosperity: The Terawatt Challenge. MRS Bull. 2005, 30 (6), 412-417.

(3) WWAP (United Nations World Water Assessment Programme). The United Nations World Water Development Report 2017: Wastewater The Untapped Rescource; UNESCO: Paris, 2017.

(4) Garcia-Segura, S.; Ocon, J. D.; Chong, M. N. Electrochemical Oxidation Remediation of Real Wastewater Effluents - A Review. Process Saf. Environ. Prot. 2018, 113, 48-67.

(5) Margot, J.; Rossi, L.; Barry, D. A.; Holliger, C. A Review of the Fate of Micropollutants in Wastewater Treatment Plants. Wiley Interdiscip. Rev.: Water 2015, 2 (5), 457-487.

(6) Luo, Y.; Guo, W.; Ngo, H. H.; Nghiem, L. D.; Hai, F. I.; Zhang, J.; Liang, S.; Wang, X. C. A Review on the Occurrence of Micropollutants in the Aquatic Environment and Their Fate and Removal during Wastewater Treatment. Sci. Total Environ. 2014, 473-474, 619-641.

(7) Gupta, A.; Thakur, I. S. Treatment of Organic Recalcitrant Contaminants in Wastewater. In Biological Wastewater Treatment and Resource Recovery; Farooq, R., Ahmad, Z., Eds.; InTech, 2017. https:// doi.org/10.5772/66346.

(8) Lefebvre, O.; Moletta, R. Treatment of Organic Pollution in Industrial Saline Wastewater: A Literature Review. Water Res. 2006, 40 (20), 3671-3682.

(9) Kargi, F.; Dincer, A. R. Effect of Salt Concentration on Biological Treatment of Saline Wastewater by Fed-Batch Operation. Enzyme Microb. Technol. 1996, 19 (7), 529-537.

(10) Dewil, R.; Mantzavinos, D.; Poulios, I.; Rodrigo, M. A. New Perspectives for Advanced Oxidation Processes. J. Environ. Manage. 2017, 195, 93-99.

(11) Comninellis, C.; Nerini, A. Anodic Oxidation of Phenol in the Presence of $\mathrm{NaCl}$ for Wastewater Treatment. J. Appl. Electrochem. 1995, 25 (1), 23-28.

(12) Panizza, M.; Cerisola, G. Electrochemical Oxidation of 2Naphthol with in Situ Electrogenerated Active Chlorine. Electrochim. Acta 2003, 48 (11), 1515-1519.

(13) Panizza, M.; Cerisola, G. Direct And Mediated Anodic Oxidation of Organic Pollutants. Chem. Rev. 2009, 109 (12), 65416569.

(14) Martinez-Huitle, C. A.; Ferro, S. Electrochemical Oxidation of Organic Pollutants for the Wastewater Treatment: Direct and Indirect Processes. Chem. Soc. Rev. 2006, 35 (12), 1324-1340. 
(15) Sirés, I.; Brillas, E.; Oturan, M. A.; Rodrigo, M. A.; Panizza, M. Electrochemical Advanced Oxidation Processes: Today and Tomorrow. A Review. Environ. Sci. Pollut. Res. 2014, 21 (14), 8336-8367.

(16) Saylor, G. L.; Chen, L.; Kupferle, M. J. Using Toxicity Testing to Evaluate Electrochemical Reactor Operations. Environ. Toxicol. Chem. 2012, 31 (3), 494-500.

(17) Jasper, J. T.; Yang, Y.; Hoffmann, M. R. Toxic Byproduct Formation during Electrochemical Treatment of Latrine Wastewater. Environ. Sci. Technol. 2017, 51 (12), 7111-7119.

(18) Li, H.; Long, Y.; Zhu, X.; Tian, Y.; Ye, J. Influencing Factors and Chlorinated Byproducts in Electrochemical Oxidation of Bisphenol A with Boron-Doped Diamond Anodes. Electrochim. Acta 2017, 246, 1121-1130.

(19) Burgos-Castillo, R. C.; Sirés, I.; Sillanpää, M.; Brillas, E. Application of Electrochemical Advanced Oxidation to Bisphenol A Degradation in Water. Effect of Sulfate and Chloride Ions. Chemosphere 2018, 194, 812-820.

(20) Chaplin, B. P. Critical Review of Electrochemical Advanced Oxidation Processes for Water Treatment Applications. Environ. Sci. Process. Impacts 2014, 16 (6), 1182-1203.

(21) Hanberg, A. Toxicology of Environmentally Persistent Chlorinated Organic Compounds. Pure Appl. Chem. 1996, 68 (9), 1791-1799.

(22) Schoeny, R. Disinfection By-Products: A Question of Balance. Environ. Health Perspect. 2010, 118 (11), A466-A467.

(23) Villanueva, C. M.; Cordier, S.; Font-Ribera, L.; Salas, L. A.; Levallois, P. Overview of Disinfection By-Products and Associated Health Effects. Curr. Environ. Heal. reports 2015, 2 (1), 107-115.

(24) Lindner, M.; Bahnemann, D. W.; Hirthe, B.; Griebler, W. D. Solar Water Detoxification: Novel TiO2 Powders as Highly Active Photocatalysts. J. Sol. Energy Eng. 1997, 119 (2), 120-125.

(25) Burns, R. A.; Crittenden, J. C.; Hand, D. W.; Selzer, V. H.; Sutter, L. L.; Salman, S. R. Effect of Inorganic Ions in Heterogeneous Photocatalysis of TCE. J. Environ. Eng. 1999, 125 (1), 77-85.

(26) Calza, P.; Pelizzetti, E. Photocatalytic Transformation of Organic Compounds in the Presence of Inorganic Ions. Pure Appl. Chem. 2001, 73, 1839.

(27) Yang, S.; Chen, Y.; Lou, L.; Wu, X. Involvement of Chloride Anion in Photocatalytic Process. J. Environ. Sci. 2005, 17 (5), 761765 .

(28) Chen, H. Y.; Zahraa, O.; Bouchy, M. Inhibition of the Adsorption and Photocatalytic Degradation of an Organic Contaminant in an Aqueous Suspension of $\mathrm{TiO} 2$ by Inorganic Ions. J. Photochem. Photobiol., A 1997, 108 (1), 37-44.

(29) Zhang, W.; An, T.; Cui, M.; Sheng, G.; Fu, J. Effects of Anions on the Photocatalytic and Photoelectrocatalytic Degradation of Reactive Dye in a Packed-Bed Reactor. J. Chem. Technol. Biotechnol. 2005, 80 (2), 223-229.

(30) Chong, M. N.; Jin, B.; Chow, C. W. K.; Saint, C. Recent Developments in Photocatalytic Water Treatment Technology: A Review. Water Res. 2010, 44 (10), 2997-3027.

(31) Umar, M.; Abdul Aziz, H. Photocatalytic Degradation of Organic Pollutants in Water. In Organic Pollutants-Monitoring, Risk and Treatment; Nageeb Rashed, M., Ed.; InTech, 2013. https://doi. org/10.5772/53699.

(32) Krivec, M.; Dillert, R.; Bahnemann, D. W.; Mehle, A.; Strancar, J.; Drazic, G. The Nature of Chlorine-Inhibition of Photocatalytic Degradation of Dichloroacetic Acid in a TiO2-Based Microreactor. Phys. Chem. Chem. Phys. 2014, 16 (28), 14867-14873.

(33) Guillard, C.; Puzenat, E.; Lachheb, H.; Houas, A.; Herrmann, J.-M. Why Inorganic Salts Decrease the $\mathrm{TiO} 2$ Photocatalytic Efficiency. Int. J. Photoenergy 2005, 7 (1), 1-9.

(34) Sunada, F.; Heller, A. Effects of Water, Salt Water, and Silicone Overcoating of the $\mathrm{TiO} 2$ Photocatalyst on the Rates and Products of Photocatalytic Oxidation of Liquid 3-Octanol and 3-Octanone. Environ. Sci. Technol. 1998, 32 (2), 282-286.

(35) Abdullah, M.; Low, G. K. C.; Matthews, R. W. Effects of Common Inorganic Anions on Rates of Photocatalytic Oxidation of
Organic Carbon over Illuminated Titanium Dioxide. J. Phys. Chem. 1990, 94 (17), 6820-6825.

(36) Piscopo, A.; Robert, D.; Weber, J. V. Influence of PH and Chloride Anion on the Photocatalytic Degradation of Organic Compounds. Appl. Catal., B 2001, 35 (2), 117-124.

(37) Sökmen, M.; Özkan, A. Decolourising Textile Wastewater with Modified Titania: The Effects of Inorganic Anions on the Photocatalysis. J. Photochem. Photobiol., A 2002, 147 (1), 77-81.

(38) Azevedo, E. B.; Neto, F. R. de A.; Dezotti, M. TiO2Photocatalyzed Degradation of Phenol in Saline Media: Lumped Kinetics, Intermediates, and Acute Toxicity. Appl. Catal., B 2004, 54 (3), 165-173.

(39) Yuan, R.; Ramjaun, S. N.; Wang, Z.; Liu, J. Photocatalytic Degradation and Chlorination of Azo Dye in Saline Wastewater: Kinetics and AOX Formation. Chem. Eng. J. 2012, 192, 171-178.

(40) Adishkumar, S.; Kanmani, S.; Rajesh Banu, J. Solar Photocatalytic Treatment of Phenolic Wastewaters: Influence of Chlorides, Sulphates, Aeration, Liquid Volume and Solar Light Intensity. Desalin. Water Treat. 2014, 52 (40-42), 7957-7963.

(41) Pellegrino, F.; Pellutiè, L.; Sordello, F.; Minero, C.; Ortel, E.; Hodoroaba, V. D.; Maurino, V. Influence of Agglomeration and Aggregation on the Photocatalytic Activity of $\mathrm{TiO}_{2}$ Nanoparticles. Appl. Catal., B 2017, 216, 80-87.

(42) Lamour, R; Azevedo, E; Leite, S; Dezotti, M Removal of Phenol in High Salinity Media by a Hybrid Process (Activated Sludge +photocatalysis). Sep. Purif. Technol. 2008, 60 (2), 142-146.

(43) Azevedo, E. B.; Tôrres, A. R.; Aquino Neto, F. R.; Dezotti, M. TiO2-Photocatalyzed Degradation of Phenol in Saline Media in an Annular Reactor: Hydrodynamics, Lumped Kinetics, Intermediates, and Acute Toxicity. Braz. J. Chem. Eng. 2009, 26, 75-87.

(44) Henderson, M. A. A Surface Science Perspective on $\mathrm{TiO}_{2}$ Photocatalysis. Surf. Sci. Rep. 2011, 66 (6), 185-297.

(45) Yang, Y.; Pignatello, J. Participation of the Halogens in Photochemical Reactions in Natural and Treated Waters. Molecules 2017, 22 (10), 1684.

(46) Su, Y.-f.; Wang, G.-B.; Kuo, D. T. F.; Chang, M.-1.; Shih, Y. Photoelectrocatalytic Degradation of the Antibiotic Sulfamethoxazole Using TiO2/Ti Photoanode. Appl. Catal. B Environ. 2016, 186, 184192.

(47) Ghernaout, D.; Naceur, M. W.; Aouabed, A. On the Dependence of Chlorine By-Products Generated Species Formation of the Electrode Material and Applied Charge during Electrochemical Water Treatment. Desalination 2011, 270 (1-3), 9-22.

(48) Radjenovic, J.; Sedlak, D. L. Challenges and Opportunities for Electrochemical Processes as Next-Generation Technologies for the Treatment of Contaminated Water. Environ. Sci. Technol. 2015, 49 (19), 11292-11302.

(49) Bessegato, G. G.; Guaraldo, T. T.; de Brito, J. F.; Brugnera, M. F.; Zanoni, M. V. B. Achievements and Trends in Photoelectrocatalysis: From Environmental to Energy Applications. Electrocatalysis 2015, 6 (5), 415-441.

(50) Garcia-Segura, S.; Brillas, E. Applied Photoelectrocatalysis on the Degradation of Organic Pollutants in Wastewaters. J. Photochem. Photobiol., C 2017, 31, 1-35.

(51) Hao, Z.; Yin, Y.; Wang, J.; Cao, D.; Liu, J. Formation of Organobromine and Organoiodine Compounds by Engineered TiO2nanoparticle-Induced Photohalogenation of Dissolved Organic Matter in Environmental Waters. Sci. Total Environ. 2018, 631-632, $158-168$.

(52) Zhang, K.; Parker, K. M. Halogen Radical Oxidants in Natural and Engineered Aquatic Systems. Environ. Sci. Technol. 2018, 52 (17), 9579.

(53) Selcuk, H.; Bekbolet, M. Photocatalytic and Photoelectrocatalytic Humic Acid Removal and Selectivity of $\mathrm{TiO}_{2}$ coated Photoanode. Chemosphere 2008, 73 (5), 854-858.

(54) Zhang, F.; Li, M.; Li, W.; Feng, C.; Jin, Y.; Guo, X.; Cui, J. Degradation of Phenol by a Combined Independent Photocatalytic and Electrochemical Process. Chem. Eng. J. 2011, 175 (1), 349-355. 
(55) Osiewała, L.; Socha, A.; Perek, A.; Socha, M.; Rynkowski, J. Electrochemical, Photochemical, and Photoelectrochemical Treatment of Sodium p-Cumenesulfonate. Water. Air. Soil Pollut. 2013, 224 (9) DOI: $10.1007 / \mathrm{s} 11270-013-1657-3$.

(56) Hurwitz, G.; Pornwongthong, P.; Mahendra, S.; Hoek, E. M. V. Degradation of Phenol by Synergistic Chlorine-Enhanced PhotoAssisted Electrochemical Oxidation. Chem. Eng. J. 2014, 240, 235243.

(57) Tantis, I.; Bousiakou, L.; Karikas, G.-A.; Lianos, P. Photocatalytic and Photoelectrocatalytic Degradation of the Antibacterial Agent Ciprofloxacin. Photochem. Photobiol. Sci. 2015, 14 (3), 603607.

(58) Suhadolnik, L.; Pohar, A.; Likozar, B.; Čeh, M. Mechanism and Kinetics of Phenol Photocatalytic, Electrocatalytic and Photoelectrocatalytic Degradation in a TiO2-Nanotube Fixed-Bed Microreactor. Chem. Eng. J. 2016, 303, 292-301.

(59) Serna-Galvis, E. A.; Silva-Agredo, J.; Giraldo, A. L.; FlórezAcosta, O. A.; Torres-Palma, R. A. Comparative Study of the Effect of Pharmaceutical Additives on the Elimination of Antibiotic Activity during the Treatment of Oxacillin in Water by the Photo-Fenton, TiO2-Photocatalysis and Electrochemical Processes. Sci. Total Environ. 2016, 541, 1431-1438.

(60) Granda-Ramírez, C. F.; Hincapié-Mejía, G. M.; Serna-Galvis, E. A.; Torres-Palma, R. A. Degradation of Recalcitrant Safranin T Through an Electrochemical Process and Three Photochemical Advanced Oxidation Technologies. Water. Air. Soil Pollut. 2017, 228 (11) DOI: $10.1007 / \mathrm{s} 11270-017-3611-2$.

(61) Cao, D.; Wang, Y.; Zhao, X. Combination of Photocatalytic and Electrochemical Degradation of Organic Pollutants from Water. Curr. Opin. Green Sustain. Chem. 2017, 6, 78-84.

(62) Escudero, C. J.; Iglesias, O.; Dominguez, S.; Rivero, M. J.; Ortiz, I. Performance of Electrochemical Oxidation and Photocatalysis in Terms of Kinetics and Energy Consumption. New Insights into the p-Cresol Degradation. J. Environ. Manage. 2017, 195, 117124.

(63) Carneiro, J. T.; Savenije, T. J.; Moulijn, J. A.; Mul, G. Toward a Physically Sound Structure-Activity Relationship of TiO2-Based Photocatalysts. J. Phys. Chem. C 2010, 114 (1), 327-332.

(64) Romão, J. S.; Hamdy, M. S.; Mul, G.; Baltrusaitis, J. Photocatalytic Decomposition of Cortisone Acetate in Aqueous Solution. J. Hazard. Mater. 2015, 282, 208-215.

(65) Boitsov, S.; Mjøs, S. A.; Meier, S. Identification of Estrogen-like Alkylphenols in Produced Water from Offshore Oil Installations. Mar. Environ. Res. 2007, 64 (5), 651-665.

(66) Priac, A.; Morin-Crini, N.; Druart, C.; Gavoille, S.; Bradu, C.; Lagarrigue, C.; Torri, G.; Winterton, P.; Crini, G. Alkylphenol and Alkylphenol Polyethoxylates in Water and Wastewater: A Review of Options for Their Elimination. Arabian J. Chem. 2017, 10, S3749S3773.

(67) Kochukov, M. Y.; Jeng, Y. J.; Watson, C. S. Alkylphenol Xenoestrogens with Varying Carbon Chain Lengths Differentially and Potently Activate Signaling and Functional Responses in GH3/B6/ F10 Somatomammotropes. Environ. Health Perspect. 2009, 117 (5), 723-730.

(68) Reckhow, D. A.; Singer, P. C.; Malcolm, R. L. Chlorination of Humic Materials: Byproduct Formation and Chemical Interpretations. Environ. Sci. Technol. 1990, 24 (11), 1655-1664.

(69) Bond, T.; Henriet, O.; Goslan, E. H.; Parsons, S. A.; Jefferson, B. Disinfection Byproduct Formation and Fractionation Behavior of Natural Organic Matter Surrogates. Environ. Sci. Technol. 2009, 43 (15), 5982-5989.

(70) Lee, G. F.; Morris, J. C. Kinetics of Chlorination of PhenolChlorophenolic Tastes and Odors. Int.J.Air Wat.Poll. 1962, 6 (567), 419-431.

(71) Rule, K. L.; Ebbett, V. R.; Vikesland, P. J. Formation of Chloroform and Chlorinated Organics by Free-Chlorine-Mediated Oxidation of Triclosan. Environ. Sci. Technol. 2005, 39 (9), 31763185.
(72) Onodera, S.; Yamada, K.; Jamaji, Y.; Ishikura, S.; Suzuki, S. Chemical Changes of Organic Compounds in Chlorinated Water: X. Formation of Polychlorinated Methylphenoxymethylphenols (Predioxins) during Chlorination of Methylphenols in Dilute Aqueous Solution. J. Chromatogr. 1986, 354, 293-303.

(73) Onodera, S.; Tabata, M.; Suzuki, S.; Ishikura, S. Gas Chromatographic Identification and Determination of Chlorinated Quinones Formed during Chlorination of Dihydric Phenols with Hypochlorite in Dilute Aqueous Solution. J. Chromatogr. 1980, 200, 137-144.

(74) Vallejo, M.; San Román, M. F.; Ortiz, I. Quantitative Assessment of the Formation of Polychlorinated Derivatives, $\mathrm{PCDD} / \mathrm{Fs}$, in the Electrochemical Oxidation of 2-Chlorophenol As Function of the Electrolyte Type. Environ. Sci. Technol. 2013, 47 (21), 12400-12408.

(75) Chen, L.; Campo, P.; Kupferle, M. J. Identification of Chlorinated Oligomers Formed during Anodic Oxidation of Phenol in the Presence of Chloride. J. Hazard. Mater. 2015, 283, 574-581.

(76) Zöllig, H.; Remmele, A.; Fritzsche, C.; Morgenroth, E.; Udert, K. M. Formation of Chlorination Byproducts and Their Emission Pathways in Chlorine Mediated Electro-Oxidation of Urine on Active and Nonactive Type Anodes. Environ. Sci. Technol. 2015, 49 (18), 11062-11069.

(77) Mostafa, E.; Reinsberg, P.; Garcia-Segura, S.; Baltruschat, H. Chlorine Species Evolution during Electrochlorination on BoronDoped Diamond Anodes: In-Situ Electrogeneration of $\mathrm{Cl} 2, \mathrm{Cl} 2 \mathrm{O}$ and ClO2. Electrochim. Acta 2018, 281, 831-840.

(78) Kosmulski, M. PH-Dependent Surface Charging and Points of Zero Charge. IV. Update and New Approach. J. Colloid Interface Sci. 2009, 337 (2), 439-448.

(79) Dunn, W. W.; Aikawa, Y.; Bard, A. J. Characterization of Particulate Titanium Dioxide Photocatalysts by Photoelectrophoretic and Electrochemical Measurements. J. Am. Chem. Soc. 1981, 103 (12), 3456-3459.

(80) Boxall, C.; Kelsall, G. H. Photoelectrophoresis of Colloidal Semiconductors, Part 1.- The Technique and Its Applications. J. Chem. Soc., Faraday Trans. 1991, 87 (21), 3537-3545.

(81) Vidal, A.; Herrero, J.; Romero, M.; Sanchez, B.; Sanchez, M. Heterogeneous Photocatalysis: Degradation of Ethylbenzene in $\mathrm{TiO} 2$ Aqueous Suspensions. J. Photochem. Photobiol., A 1994, 79 (3), 213219.

(82) Dang, T. T. T.; Le, S. T. T.; Channei, D.; Khanitchaidecha, W.; Nakaruk, A. Photodegradation Mechanisms of Phenol in the Photocatalytic Process. Res. Chem. Intermed. 2016, 42 (6), 59615974.

(83) Khunphonoi, R.; Grisdanurak, N. Mechanism Pathway and Kinetics of P-Cresol Photocatalytic Degradation over Titania Nanorods under UV-Visible Irradiation. Chem. Eng. J. 2016, 296, $420-427$

(84) Gligorovski, S.; Strekowski, R.; Barbati, S.; Vione, D. Environmental Implications of Hydroxyl Radicals $(\bullet \mathrm{OH})$. Chem. Rev. 2015, 115 (24), 13051-13092.

(85) Devi, L. G.; Krishnamurthy, G. TiO2- and BaTiO3-Assisted Photocatalytic Degradation of Selected Chloroorganic Compounds in Aqueous Medium: Correlation of Reactivity/Orientation Effects of Substituent Groups of the Pollutant Molecule on the Degradation Rate. J. Phys. Chem. A 2011, 115 (4), 460-469.

(86) Pang, X.; Chen, C.; Ji, H.; Che, Y.; Ma, W.; Zhao, J. Unraveling the Photocatalytic Mechanisms on TiO2surfaces Using the Oxygen18 Isotopic Label Technique. Molecules 2014, 19 (10), 16291-16311.

(87) Zanoni, M. V. B.; Sene, J. J.; Selcuk, H.; Anderson, M. A. Photoelectrocatalytic Production of Active Chlorine on Nanocrystalline Titanium Dioxide Thin-Film Electrodes. Environ. Sci. Technol. 2004, 38 (11), 3203-3208.

(88) An, T.; Zhang, W.; Xiao, X.; Sheng, G.; Fu, J.; Zhu, X. J. Photochem. Photobiol., A 2004, 161, 233-242.

(89) Selcuk, H. Disinfection and Formation of Disinfection ByProducts in a Photoelectrocatalytic System. Water Res. 2010, 44 (13), 3966-3972. 
(90) Boxall, C. The Electrophoresis of Semiconductor Particles. Chem. Soc. Rev. 1994, 23, 137-145. 